\title{
The Effect of Leadership Style on Employee Performance of the PPIC Division of PT. Prima Components Indonesia BSD-Tangerang
}

\author{
Suyatin \\ Universitas Pamulang \\ E-mail: dosen01426@ unpam.ac.id
}

(Received: March-2019; Reviewed: April-2019; Accepted: Juny-2019;

Avalaibel Online: September-2019; Published: September -2019)

This is an open access article distributed under the Creative Commons Attribution License CC-BY-NC-4.0 (C2019 by author (https://creativecommons.org/licenses/by-nc/4.0/)

\begin{abstract}
The automotive industry is one of the mainstay sectors whose development continues to be prioritized. The purpose of this study was to determine the effect of leadership style on the performance of the employees of PT. Prima Components Indonesia BSD-Tangerang. The research method uses quantitative, saturated sampling, which means that the entire population is sampled as many as 45 respondents. Statistical tests use simple linear regression equations, correlation coefficient tests, determination coefficient tests, and significance tests. The results of the study found that there was an influence of leadership style on the performance of employees of the PPIC Division of the Department of PT. Prima Components Indonesia BSD-Tangerang, based on the results of data analysis shows that from the correlation of 0.619 it can be concluded that there is a strong influence between leadership style on the employee performance of the PPIC Division of the Department of PT. Prima Components Indonesia BSD-Tangerang, The results of the coefficient of the determination indicate that the leadership style contributes $38.3 \%$ to employee performance, the remaining $61.7 \%$ is influenced by other variables. Simple linear regression equation $\mathrm{Y}=1.454+0.629 \mathrm{X}$ In the hypothesis test $\mathrm{t}_{\text {count }} 5.163>\mathrm{t}_{\text {table }} 1.68$ then $\mathrm{Ho}$ is rejected $\mathrm{H} 1$ is accepted, meaning that there is a significant influence between leadership style on employee performance at the PPIC Department of PT. Prima Components Indonesia BSD-Tangerang.
\end{abstract}

Keywords: Leadership style; performance; employee

\section{INTRODUCTION}

The automotive industry is one of the mainstay sectors whose development continues to be prioritized because it plays a major role in national economic growth (Setiawan, 2017; Susilowati, Hutagaol, Pasaribu, \& Djohar, 2013; Tridoyo \& Sriyanto, 2014). The Indonesian automotive industry has become an important pillar in the country's manufacturing sector because many world-renowned car companies are reopening car manufacturing factories or increasing their production capacity in Indonesia, the country with the largest economy in Southeast Asia. Moreover, Indonesia has experienced a remarkable transition because it has 
changed from being just a place for car production to be exported, especially for the Southeast Asian region, to a large domestic car sales market due to an increase in gross domestic product per capita (Denny Sentia, Asmadi, \& Ramadhan, 2016; Farid \& Iwan Indrawan Wiratmadja, 2011; Indonesia investement, 2017).

Indonesia has the second-largest car manufacturing industry in Southeast Asia and in the ASEAN region (after Thailand which controls about 50 percent of car production in the ASEAN region). Nevertheless, because of its fertile growth in recent years, Indonesia will increasingly threaten Thailand's dominant position over the coming decade. However, to overtake Thailand as the largest car manufacturer in the ASEAN region, it will require major efforts and breakthroughs. At present Indonesia is highly dependent on foreign direct investment, especially from Japan, for the establishment of car manufacturing facilities. Indonesia also needs to develop a car component industry that can support the car manufacturing industry. At present, the total production capacity of cars assembled in Indonesia stands at around two million units per year (Ibrahim, 2019; Yusuf W, Pratikto, \& Vivianne, 2009).

Leadership style implies understanding as an embodiment of the behavior of a leader, which involves his ability to lead (Batista-Taran, Shuck, Gutierrez, \& Baralt, 2017; Elvasusanti, Syamsudduha, \& Rahman, 2019; Niswaty, Juniati, Darwis, Salam, \& Arhas, 2019; Riyadi, 1945; Situmorang, 2011; Sudaryono, 2014; Sunarsi, 2014, 2017, 2018a, 2018b; Sutikno, 2014; Wader, Darwis, Salam, \& Baharuddin, 2020). This embodiment usually forms a certain pattern or form. Conversely, the leadership style that is not adjusted to the characteristics of employees and existing tasks, can encourage employees to feel less eager to work or even lose their morale, causing employees to not be serious in their work and attention that is not centered on the job (Dewi, 2018; Nimpuno, 2015; Reza, 2010). In carrying out company activities employees must understand the importance of being responsible in achieving company goals (Dessler, 2015; Hasibuan, 2011; Yani, 2011). To achieve the success of the company, especially in companies engaged in the automotive sector such as at PT. Prima Components Indonesia BSD-Tangerang must be able to reach the High Customer Service Level, meaning that it can fulfill all Customer Orders reaching the target of $100 \%$ and be able to satisfy the Customer. However, it can be seen in the following table, in the process of shipping goods carried out by the PPIC Division of PT. Prima Components Indonesia that the high number of complaints to consumers is caused by the number of employees who ignore the responsibility in achieving company goals.

In the process of shipping goods to consumers, the PPIC Division is inseparable from mistakes that cause complaints from consumers. Complaints occur because there is a mismatch in the delivery process to the consumer, shipping is not in accordance with the goods in the travel document, shipping that is not in accordance with the amount on the travel document, delivery is not on time and other errors in the shipping process that cause consumer complaints. Another problem found in companies is the tendency where employees are less able to increase the amount of work, which is one of the factors causing complaints in the delivery process to consumers. In this problem, the role of the leader as observer and developer of the potentials of the employees is also important so that they can improve their performance. It can be seen in the following table, that the number of jobs completed by employees is still low and not in line with company expectations. Apart from the number of jobs that do not reach their monthly targets, another cause of consumer complaints is the production quality that is not optimal. High Quality is another achievement desired by a company (Arian, 2014; Ariani, 2016; Assauri, 2008) .

High Quality related to the PPIC Division is that even though it must meet the objectives of the High Customer Service Level, the main product quality remains, in this case, PPIC related is issuing a PR (Purchase Request) to Purchasing and issuing a MO (Manufacturing Order) to Production, must be in accordance with Leadtime, the period of time between the customer's order and the delivery of the final product that has been agreed by all parties. Because Leadtime 
that is less than the provisions will trigger low quality and high production costs. Leaders must be firm about the agreed lead time so that the quality of the company's production gets good results.

A leader should be able to develop the human resources available to be developed continuously, in order to obtain quality human resources, in the true sense that the work carried out will produce something that is desired (Edison, Anwar, \& Komariyah, 2016; Marwansyah, 2010; Notoatmojo, 2010; Wirawan, 2015). By changing the leadership style that is acceptable to employees, employees can carry out their duties and responsibilities better so that company goals can be achieved to the maximum (Rivai \& Mulyadi, 2012; Sri Wiranti, 2009; Yudiaatmaja, 2013). Therefore, the leadership style is very important and needs to be considered by a leader. With an appropriate leadership style, a leader must be able to communicate well and be able to work together in terms of duties and responsibilities.

\section{METHOD}

This type of research used in this research is descriptive research with a quantitative approach. The population in this study were employees of the PPIC Division of PT. Prima Components Indonesia as many as 45 people. This study uses a sampling technique that is Nonprobability sampling which is included in saturated sampling, which is the technique of determining the sample when all members of the population are used as samples. There are several ways to obtain data, namely observation and questionnaire. The data quality test used is the validity test and reliability test. Inferential statistical analysis used namely correlation coefficient $(r)$, coefficient of determination $\left(r^{2}\right)$, simple linear regression analysis and hypothesis testing

\section{RESULT AND DISCUSSION}

PT. Prima Komponen Indonesia is a company engaged in the Automotive Component Parts Manufacturer which produces several parts of car accessories needed by several companies such as PT. Astra Daihatsu Motor, PT. Toyota Astra Motor, PT. Kramayuda Tiga Berlian, PT. Isuzu Astra Motor, PT. Honda Prospect Motor etc. To meet these needs the company is required to be able to work on orders within the specified time so that the application of productivity methods can help achieve this by taking into account the number of inputs and outputs achieved by the company

\section{Correlation Coefficient Test Results (r)}

To be able to know the strength of the level or degree of closeness of the relationship between the variables studied, the guideline criteria table is used for the correlation coefficient in accordance (Sugiyono, 2016). 
By using SPSS 21.0 program, the following correlation values are obtained.

Table 1.

Correlation Test Results X and Y

\begin{tabular}{|c|c|c|c|}
\hline \multicolumn{4}{|c|}{ Correlations } \\
\hline & & Employee & Leadership Style \\
\hline & & Performance & \\
\hline \multirow{2}{*}{ Pearson Correlation } & Employee Performance & 1,000 & ,619 \\
\hline & Leadership Style & ,619 & 1,000 \\
\hline \multirow{2}{*}{ Sig. (1-tailed) } & Employee Performance & . &, 000 \\
\hline & Leadership Style & , 000 & \\
\hline \multirow{2}{*}{$\mathrm{N}$} & Employee Performance & 45 & 45 \\
\hline & Leadership Style & 45 & 45 \\
\hline
\end{tabular}

Data source: Processed SPSS output, 2017

Based on table 1 obtained correlation coefficient values of 0.619 . This implies that the relationship of leadership style to employee performance is strong at the interval of interpretation of the correlation coefficient of $0.60-0.799$.

\section{Determination Coefficient Test Results (R Square)}

The value used in the coefficient of determination is to use the value of $\mathrm{R}$ Square. This value is used to measure how much the model's ability to explain the dependent variable. The $\mathrm{R}$ Square value used is taken from the summary model table.

Table 2.

Determination Coefficient Test Results (R Square)

\begin{tabular}{|c|c|c|c|c|c|}
\hline \multicolumn{6}{|c|}{ Model Summary ${ }^{b}$} \\
\hline Model & $\mathrm{R}$ & R Square & $\begin{array}{l}\text { Adjusted R } \\
\text { Square } \\
\end{array}$ & $\begin{array}{l}\text { Std. Error of the } \\
\text { Estimate }\end{array}$ & Durbin-Watson \\
\hline 1 &, $619^{\mathrm{a}}$ & ,383 & ,368 &, 35503 & 2,190 \\
\hline
\end{tabular}

Based on table 2 obtained the value of $R=0.619$ and the coefficient of determination ( $R$ Square) of 0.383 . This shows the understanding that employee performance (Y) is influenced by $38.3 \%$ while the rest of $(100 \%-38.3 \%=61.7 \%)$ is influenced by other variables not examined by researchers.

\section{Simple Linear Regression Test}

Simple Linear Regression Analysis is a linear relationship between one independent variable $(\mathrm{X})$ and the dependent variable $(\mathrm{Y})$. This analysis is to determine the direction of the relationship between variables. By using SPSS 21 program, the following values for simple regression are obtained. 
Table 3

Simple Regression Test Results

Coefficients $^{\mathrm{a}}$

\begin{tabular}{|c|c|c|c|c|c|c|}
\hline & \multirow[t]{2}{*}{ Model } & \multicolumn{2}{|c|}{$\begin{array}{l}\text { Unstandardized } \\
\text { Coefficients }\end{array}$} & \multirow{2}{*}{$\begin{array}{c}\text { Standardized } \\
\text { Coefficients }\end{array}$} & \multirow[t]{2}{*}{$\mathrm{t}$} & \multirow[t]{2}{*}{ Sig. } \\
\hline & & $\mathrm{B}$ & Std. Error & & & \\
\hline \multirow[t]{2}{*}{1} & (Constant) & 1,454 & ,509 & & 2,854 & ,007 \\
\hline & Leadership Style & 629, & , 122 & 619 & 5,163 & 000 \\
\hline
\end{tabular}

a. Dependent Variable: Employee Performance

Data source: Processed SPSS output, 2017

Based on the output of the regression analysis in the Coefficient table, the constant in the equation above the constant value is 1.454 which means that if the score on the leadership style variable is equal to zero then the employee's performance will be 1.454. The leadership style in the equation above is obtained at 0.629 with Sig. 0,000 , which means positive direction and if the score on the leadership style variable increases, employee performance will increase and vice versa if the score of the leadership style variable decreases, employee performance will decrease, assuming other variables are equal to zero or in a constant state. Thus, the regression equation can be written as follows:

$\mathrm{Y}=1,454+0,629 \mathrm{X}$

If the independent variable $(\mathrm{X})$ increases by one unit, the dependent variable $(\mathrm{Y})$ can be predicted to increase by $0.629(63 \%)$ at a constant of 1.454 .

\section{Hypotesis Test}

To assess the level of significance of the leadership style to the company, it can be used with the statistical t-test ( $\left.\mathrm{t}_{\text {table }}\right)$. By using a significance level of $5 \%(0.05)$ and degrees of freedom (dk) with the formula $\mathrm{dk}=\mathrm{n}-\mathrm{k}$, while $\mathrm{n}$ is the number of respondents and $\mathrm{k}$ is the number of variables added.

Table 4

Partial t-Test Results

Coefficients $^{\mathrm{a}}$

\begin{tabular}{|c|c|c|c|c|c|c|}
\hline & \multirow[t]{2}{*}{ Model } & \multicolumn{2}{|c|}{$\begin{array}{l}\text { Unstandardized } \\
\text { Coefficients }\end{array}$} & \multirow{2}{*}{$\begin{array}{c}\text { Standardized } \\
\text { Coefficients } \\
\text { Beta }\end{array}$} & \multirow[t]{2}{*}{$\mathrm{t}$} & \multirow[t]{2}{*}{ Sig. } \\
\hline & & $\mathrm{B}$ & Std. Error & & & \\
\hline \multirow[t]{2}{*}{1} & (Constant) & 1,454 & ,509 & & 2,854 & ,007 \\
\hline & $\begin{array}{l}\text { Leadership } \\
\text { Style }\end{array}$ & 629 & , 122 & ,619 & 5,163 & ,000 \\
\hline
\end{tabular}

a. Dependent Variable: Employee Performance

Data source: Processed SPSS output, 2017

From table 4 it can be seen that the results of the leadership style hypothesis show the value of tcount is 5.163 with a significance level of 0.000 and a table value of 1.68 . Because of the significance value of $t<\alpha(0,000<0.05)$, according to (Ghozali, 2016; Riadi, 2016) in the statistical research book, the Sig. smaller than 0.05 , it can be concluded that the strength of the relationship between variables $X$ with $Y$ is very significant and $t_{\text {count }}>t_{\text {table }}(5.163>1.68)$, it can be concluded that it is associated with a significant force between style and employee turnover. 
These results indicate that the leadership style of the PPIC Division leader PT Prima Components Indonesia BSD-Tangerang affects the work performance of employees which includes increasing employee desire to improve employee performance to prove their abilities. Improved employee performance is inseparable from the role of PPIC Division leader PT Prima Components Indonesia BSD Tangerang who has the ability to organize all organizational needs, able to create relationships with subordinates, respect employee opinions, be able to carry out management functions namely planning, organizing, actualizing and actualizing supervision.

While based on the results of hypothesis testing, the leadership style shows a tcount of 5.163 with a significance level of 0.000 and a $t_{\text {table }}$ value of 1.68 . Because $t_{\text {count }}>t_{\text {table }}(5.163>$ $1.68)$ and $t$ significance value $<\alpha(0,000<0.05)$, it can be concluded that there is a significant influence between leadership style on employee performance.

\section{CONCLUSION}

Based on the results of the study it was found that there is a strong influence between leadership style on the performance of the PPIC Division Department employees of PT. Prima Components Indonesia BSD-Tangerang, The results of the coefficient of the determination indicate that the leadership style contributes $38.3 \%$ to employee performance, the remaining $61.7 \%$ is influenced by other variables. Simple linear regression equation $\mathrm{Y}=1.454+0.629 \mathrm{X}$ can be concluded that if the leadership style is increased by one unit, the employee's performance will increase by 0.629 and vice versa. In the hypothesis test $t_{\text {count }} 5.163>1.68$, then $\mathrm{Ho}$ is rejected $\mathrm{H} 1$ is accepted, meaning that there is a significant influence between leadership style on the employee performance of the PPIC Division of the Department of PT. Prima Components Indonesia BSD-Tangerang.

\section{REFERENCES}

Arian, D. W. (2014). Manajemen Operasi Jasa. Manajemen Operasi. https://doi.org/10.1177/004057368303900411

Ariani, W. (2016). Manajemen Kualitas. Jurnal Managemen.

Assauri, S. (2008). Manajemen Produksi dan Operasi. Jakarta: Lembaga Penerbit Fakultas Ekonomi Universitas Indonesia.

Batista-Taran, L. C., Shuck, M. B., Gutierrez, C. C., \& Baralt, S. (2017). The Role of Leadership Style in Employee Engagement. The role of leadership style in employee. https://doi.org/10.1016/1048-9843(95)90035-7

Denny Sentia, P., Asmadi, D., \& Ramadhan, D. (2016). Pengendalian Persediaan Suku Cadang Mobil Menggunakan Pendekatan Inventori Probabilistik (Studi Kasus PT. XYZ). SEMINAR NASIONAL TEKNIK INDUSTRI UNIVERSITAS GADJAH MADA 2016.

Dessler, G. (2015). Manajemen Sumber Daya Manusia. In Jakarta: Salemba Empat.

Dewi, A. R. (2018). Pengaruh Gaya Kepemimpinan, Budaya Organisasi dan Komitmen Organisasi Terhadap Kinerja Pegawai Dinas Pertanian Kabupaten Mamuju. Jurnal Bisnis, Manajemen, dan Informatika.

Edison, E., Anwar, Y., \& Komariyah, I. (2016). Manajemen Sumber Daya Manusia. In Manajemen Sumber Daya Manusia.

Elvasusanti, E., Syamsudduha, S., \& Rahman, U. (2019). The Effect of Madrasah Head Leadership Style and Work Motivation on Work Discipline of Madrasah Aliyah Teachers. 
Jurnal Ilmiah Ilmu Administrasi Publik, 9(1), 1-8.

Farid, M., \& Iwan Indrawan Wiratmadja. (2011). Pengembangan Model Service Quality Industri Jasa Otomotif. Seminar Nasional Teknik Industri dan Kongres BKSTI VI.

Ghozali, imam. (2016). Aplikasi Analisis Multivariete Dengan Program IBM SPSS 23 (Edisi 8). In Universitas Diponegoro. https://doi.org/https://doi.org/10.3929/ethz-b-000238666

Hasibuan, M. S. P. (2011). Manajemen Sumber Daya Manusia. Edisi Revisi Jakarta: Bumi Aksara.

Ibrahim, I. (2019). Penguatan Industri Kendaraan Bermotor. Majalah Ilmiah Pengkajian Industri. https://doi.org/10.29122/mipi.v8i2.3647

Indonesia investement. (2017). Industri Manufaktur Otomotif Indonesia. www.Indonesiainvestments.com.

Marwansyah. (2010). Manajemen Sumber Daya Manusia. Alfabeta: Jakarta. https://doi.org/10.1017/CBO9781107415324.004

Nimpuno, G. A. (2015). Pengaruh Displin Kerja Dan Gaya Kepemimpinan Terhadap Kinerja Karyawan UD. Pustaka Pelajar Yogyakarta.

Niswaty, R., Juniati, F., Darwis, M., Salam, R., \& Arhas, S. H. (2019). The Effectiveness of Leadership Functions Implementation in The Makassar Departement of Manpower. JPBM (Jurnal Pendidikan Bisnis dan Manajemen), 5(1), 1-10.

Notoatmojo, S. (2010). Pengembangan Sumber daya manusia. Jurnal LPPM Bidang EkoSosBudKum.

Reza, R. A. (2010). Pengaruh Gaya Kepemimpinan, Motivasi dan Disiplin Kerja Terhadap Kinerja Karyawan PT Sinar Santosa Perkasa Banjarnegara. Pengaruh Gaya Kepimpinan, Motivasi Dan Disiplin Kerja Terhadap Kinerja Karyawan Pt Sinar Santosa Perkasa Banjarnegara.

Riadi, E. (2016). Statistika Penelitian (Analisis Manual dan IBM SPSS). Yogyakarta: Andi Offset.

Rivai, V., \& Mulyadi, D. (2012). Kepemimpinan dan Perilaku Organisasi. In Kepemimpinan dan Perilaku Organisasi.

Riyadi, S. (1945). Pengaruh Kompensasi Finansial, Gaya Kepemimpinan, dan Motivasi Kerja. Jurnal Manajemen dan Kewirausahaan. https://doi.org/10.9744/jmk.13.1.40-45

Setiawan, A. (2017). Pengaruh Gaya Kepemimpinan Partisipatif terhadap Kinerja Karyawan melalui Motivasi Kerja dan Kepuasan Kerja. Agora.

Situmorang, N. Z. (2011). Gaya Kepemimpinan. Proceeding PESAT (Psikologi, Ekonomi, Sastra, Arsitektur\&Sipil) Universitas Gunadarma.

Sri Wiranti, T. S. (2009). Model Kepemimpinan Dalam Organisasi. Jurnal STIE Semarang.

Sudaryono. (2014). Leaderships: Teori dan Praktek Kepemimpinan sudaryono. Jakarta: Lentera Ilmu Cendekia.

Sugiyono. (2016). Metodologi Penelitian Kuantitatif, Kualitatif, dan R\&D. In CV Alfabeta. https://doi.org/https://doi.org/10.3929/ethz-b-000238666

Sunarsi, D. (2014). Pengaruh Gaya Kepemimpinan, Disiplin dan Motivasi Terhadap Kinerja. 
Tesis. Fakultas Ekonomi Universitas Pamulang.

Sunarsi, D. (2017). Pengaruh Kepemimpinan Dan Budaya Organisasi terhadap Kinerja Karyawan Pada Cabang Pembantu Bank DKI Pondok Labu - Jakarta Selatan. JENIUS, $1(2), 21$.

Sunarsi, D. (2018a). Pengaruh Gaya Kepemimpinan, Motivasi Dan Disiplin Kerja Terhadap Kinerja Pendidik Yayasan Marvin. Inovasi, 5(1), 1-18.

Sunarsi, D. (2018b). Pengaruh Gaya Kepemimpinan dan Disiplin Kerja Terhadap Kinerja Karyawan Pada CV. Usaha Mandiri Jakarta. JENIUS, 1(2).

Susilowati, Y., Hutagaol, P., Pasaribu, B., \& Djohar, S. (2013). Pengaruh Aspek Pengelolaan Sumber Daya Manusia Terhadap Peningkatan Kinerja Organisasi Di Industri Otomotif Di Indonesia. Journal of Technology Management.

Sutikno, S. (2014). Pemimpin dan kepemimpinan. Pemimpin Dan Kepemimpinan.

Tridoyo, \& Sriyanto. (2014). Analisis Beban Kerja Dengan Metode Full Time Equivalent Untuk Mengoptimalkan Kinerja Karyawan Pada PT Astra International Tbk-Honda Sales Operation Region Semarang. Jurnal Undip.

Wader, N., Darwis, M., Salam, R., \& Baharuddin, A. (2020). Application of the Transformational Leadership Style at the BKKBN office in South Sulawesi Province. PINISI Discretion Review, 1(1), 7-12.

Wirawan. (2015). Manajemen Sumber Daya Manusia Indonesia. In Depok.

Yani, M. (2011). Manajemen Sumber Daya Manusia. Jurnal Perspektif. https://doi.org/ISSN $1411-8637$

Yudiaatmaja, F. (2013). Kepemimpinan: Konsep; Teori dan Karakternya. Media Komunikasi.

Yusuf W, Y., Pratikto, F. R., \& Vivianne, A. S. (2009). Evaluasi Pemohon Kredit Mobil Di Pt “ $\mathrm{X}$ ” Dengan Menggunakan Teknik Data Mining Decision Tree. Prosidiing Simposium Nasional RAPI VIII. 